\title{
Modern Manners: Regency Boxing and Romantic Sociability
}

Keywords: manners, boxing, William Hazlitt, middle classes, Mary Wollstonecraft, sociability, pedestrianism

It is time to effect a revolution in female manners - time to restore to them their lost dignity - and make them, as a part of the human species, labour by reforming themselves to reform the world.

(Mary Wollstonecraft, Vindication of the Rights of Woman, 1792) ${ }^{1}$

Modesty should accompany the Fancy as its shadow. The best men were always the best behaved.

(William Hazlitt, 'The Fight', 1822)²

Despite sharing roots in the traditions of non-conformity and radicalism, William Hazlitt, essayist and polemicist, and Mary Wollstonecraft, feminist philosopher and novelist, are not generally grouped together by Romantic scholars. Still less often are the two authors (Hazlitt the boxing enthusiast and Wollstonecraft, resolutely anti-boxing) discussed in the context of popular Regency sports, such as prize-fighting, on which subject it is rightly assumed that Wollstonecraft had little sympathy or interest. Yet, paradoxical as it may seem, I want to argue here that Hazlitt's contribution to sporting literature, specifically that of the hyper-masculine and physically brutal world of boxing, in his great essay 'The Fight', published in the New Monthly Magazine in February 1822, links him to Wollstonecraft's Enlightenment feminist interest in reforming social manners and morals. The essayist's eyewitness account of going to his first boxing match, between Bill Neate and Tom Hickman on Hungerford Downs in December 1821, describes the manners and attitudes of lower-class boxers, but it judges them, I contend, against a set of manners, such as modesty, respectability and sociability, chiefly associated with, and valued by, the middle classes.

While it might easily be assumed that Hazlitt's attendance at the Hungerford fight is an example of his well-known penchant for the more dubious side of popular London life (with boxing routs ranking alongside visits to prostitutes, play houses and the 'wickedness round about Covent Garden' in attraction), ${ }^{3}$ I propose that the 'Cockney School' essayist elevates boxing from its low surroundings by recasting it as a socially acceptable experience for the middle classes in terms that emphasise what Jeffrey N. Cox has called the Cockney School's 'Huntian programme of cheerfulness and sociality'. ${ }^{4}$ Contrary to the expectations set up in its combative title, I argue that the subject of 'The Fight' is convivial middle-class masculine sociality; this is an essay that demands to be read as a discussion of modern

Romanticism 19.3 (2013): 273-290

DOI: 10.3366/rom.2013.0144

(C) Edinburgh University Press

www.euppublishing.com/rom 
male manners. 'The Fight' demonstrates the way that those manners are shaped by the sociable acts of pedestrianism, conversation, and the act of essay writing itself. Examining Hazlitt's representation of boxing through the lens of Romantic sociability, I suggest, also allows us to see the ways in which his project of refiguring the Regency boxer as the standard bearer for a middle-class version of moral masculinity recalls Mary Wollstonecraft's earlier mission to bring about a revolution in middle-class female manners.

(

As 'a rallying point for oppositional writers', ${ }^{5}$ to quote Jeffrey Cox again, the Cockney School of the 1810s and 20s to which Hazlitt belonged makes an interesting parallel to the radical literary network established in the 1790s in London around Joseph Johnson's publishing enterprise. This liberal coterie has much in common with the later Cockney School in terms of their oppositional politics and implacable anti-Toryism. But on some social grounds, the grouping differs. Wollstonecraft, together with the 'Jacobin' authors and poets William Godwin, Thomas Holcroft, Iolo Morganwg, and William Blake, formed part of a political set whose moral and humanitarian ideals included kindness to animals and opposition to blood sports alongside the weightier abolitionist cause. By contrast, some of the Cockney School radicals, notably Hazlitt, but also Keats, felt no moral compunction to avoid cruel sports. The poet Keats, perhaps hardened by the gruesome bodily sights dissections and amputations - experienced in his early profession as a dresser at Guy's hospital, counted going to boxing matches among his London entertainments. ${ }^{6}$ On Friday 4 December 1819, he headed out of London, to Crowley, to attend a major prize-fight between Jack Randall and Ned Turner, in part to divert himself - at J. H. Reynolds's suggestion - from thoughts of the death of his brother three days earlier. The poet did not mentally separate the sight and sounds of the two men slugging it out over thirty-four rounds from the subject of his versifying. Nicholas Roe tells us that Keats 'described the rapidity of Randall's blows by tapping his fingers on a windowpane', a sound concept that he later used in The Eve of St Agnes, where

the frost-wind blows,

Like Love's alarum pattering the sharp sleet

Against the window-panes

It is as if the lovers are being warned, as Roe puts it, 'to keep up their guard'?

Another member of the crowd who thronged to the 1819 contest between Randall and Turner was Byron's friend, Thomas Moore, the Irish Whig verse satirist, composer of Anacreontic odes celebrating wine, women and song, and a poet of Romantic sociability par excellence. Initially a reluctant spectator, Moore records it was 'lucky' that Randall was an Irishman since 'it gave me some sort of interest in the contest'; as it transpired, the fight was, he says:

not so horrible as I expected - Turner's face was a good deal de-humanized, but Randall (the Conqueror) had hardly a scratch - The battle lasted two hours \& 22 minutes - A beautiful sunshine broke out at this part of day, and had there been a proportionate mixture of women in the immense ring formed around, it would have been a very brilliant spectacle-The pigeons let off at different periods of the fight with dispatches very picturesque. $^{8}$

In keeping with his reputation as the poet of sentimental and amatory verse, the Cowley fight is lodged in Moore's imagination as a scene bordering on the 'picturesque' in which the gory details of the contest all but recede before the more obviously pleasing aspects of 
the event: the enduring image of Moore's description is the sight of the carrier pigeons gathered for release into the wintry sunshine with their messages of hope and disappointment, against which the boxers themselves all but fade into the background. In a way not dissimilar to Hazlitt's representation of the Neate/Hickman contest Moore's journal entry on the Randall/Turner fight emphasises the companionable features of a celebrity prize match over and above the inherently violent purpose of a boxing rout.

From a different perspective, the sport of boxing and the Irish fighter Randall in particular also made a lasting impression on Keats's contemporary: that humanitarian poet and representative of the rural underclasses, John Clare. Following his incarceration in 1837 at the High Beech Asylum Clare, who came to believe he was Byron, or 'Boxer Byron', as he referred to the noble Lord in a sexually-charged fragment of 1840 that unites his obsession with sex and boxing during his confinement at that time, ${ }^{9}$ assumed the persona of the prize-fighter Randall. A second note on boxing, written in May 1840, is the sentence-long pugilistic paragraph, 'Jack Randalls Challenge To All the World': ${ }^{10}$

Jack Randall The Champion Of The Prize Ring Begs Leave To Inform The Sporting World That He is Ready to Meet Any Customer In The Ring Or On The Stage To Fight For The Sum Of $£ 500$ or $£ 1000$ Aside A Fair Stand Up Fight half Minute Time Win Or Loose-he Is Not Particular As To Weight Colour Or Country-All He Wishes Is To Meet With A Customer Who Has Pluck Enough To Come To The Scratch Jack Randall ${ }^{11}$

Jonathan Bate speculates that 'the persona of the pugilist became Clare's stance of defiance' in the 'tough milieu' of the High Beech Asylum, and, in the note on 'Boxer Byron', an expression of sexual lust. ${ }^{12}$ It is also possible that part of the appeal of boxing for Clare lay in the semi-secret community of the 'Fancy' (the name given to prize-fighters and the boxing fraternity) in their adoption of a 'flash' language in order to communicate undetected with other members of the coterie. 'Flash' was similar in use to 'the strange, cryptic language of the Gypsies', ${ }^{13}$ lawless migrants who exerted a fascination over a number of his poems. ${ }^{14}$ As one who existed on the social borderlines, Clare was in turn drawn towards a sympathetic identification with socially marginalised figures such as gypsies, but also boxers, who, like him, tended to be of humble origin.

There is, then, significant evidence of the popularity boxing enjoyed among poets and radicals associated with the Cockney School. And there is a growing critical interest in this area of Romantic-period culture..$^{15}$ There is also support, from the examples of Moore and Clare, that the subject of boxing could be pressed into forms of political radicalism (in Moore's case) and personal rebellion (in Clare's). One of Moore's less well-known works of 1819 is the boxing-based satire Tom Crib's Memorial to Congress. Written in the persona of 'one of the Fancy', Moore imagines Crib, the boxing champion of all England, teaching representatives of the Holy Alliance, who are depicted squabbling at the 1818 Aix-la-Chapelle conference over Europe's spoils in the wake of Napoleon's defeat, to fight fairly and cleanly. ${ }^{16}$ The radical conceit here is that a boxer of lowly origin knows better how to behave like a gentleman than Europe's leading politicians. Finally, there is the example of Hazlitt's 'The Fight', the subject of this essay. What marks out Hazlitt's essay, however, from the aforementioned literary treatments of boxing by Cockney School writers and their associates on the radical political fringe of Regency politics is, as I suggest above, its transformation of the slightly dubious subculture of boxing into a respectable spectacle for the polite middle classes. 
In comparison with the attention given by modern critics, such as Jonathan Bate, Kasia Boddy, David Higgins, Nicholas Roe, and John Strachan, ${ }^{17}$ to the interest in boxing demonstrated by a significant group of Whig-leaning British poets and Cockney School writers during the 1810s and 1820s, relatively little notice has been given to the response of the radical wing of the London-based middle-class intelligentsia to popular sports earlier in the Romantic period, in the 1790s. By reading Hazlitt in the context of Mary Wollstonecraft's project to reform female manners, I aim to highlight the sense in which Hazlitt's essay, while retaining the radical connotations that boxing has in the work of Moore and Clare, departs from existing literary treatments of boxing by radical writers in its presentation of the sport in terms of a set of highly moralised, distinctively middle-class rules of conduct that chime with

Wollstonecraft's project to bring about 'a revolution in female manners'. In tracing that involvement my aim is also to open up for the first time, albeit in preliminary fashion, the neglected history of the involvement of radical writers in the 1790s with masculine sports and popular amusements.

\section{II}

A phenomenally popular, if horribly violent and semi-legal sport, Regency boxing contests - fought bare-knuckle, without the protection of gloves - were associated with low-life gambling and drinking dens at one of the end of the social spectrum and, perhaps remarkably, with the demi-monde at the other. The Prince of Wales, his brothers the Dukes of York and Clarence, and the poet Lord Byron were well-known aficionados. Indeed, the future George IV famously appointed eighteen of the foremost pugilists of the day to act as ushers at Westminster Hall on his coronation day in July $1821 .{ }^{18}$ The literary critic and boxing historian, J. C. Reid, describes the constituency of the typical Regency boxing crowd thus:

The major bouts, with their huge audiences, were a social phenomenon of considerable significance. They brought together the King and the Commons, the wealthy and the poor, the nobles and the plebs, and excluded only the emergent middle classes, for whom pugilism was merely vulgar brawling. ${ }^{19}$

Though boxing was popular in both high and low places, Reid points out that the one social group to whom boxing did not much appeal was the cultured middle classes. Intellectuals, radicals, conservative moralists, Evangelicals, and a good portion of the Dissenting community united in their distaste for this the most manly and brutal of popular amusements. Hazlitt's close friend, the 'Cockney' radical Leigh Hunt, typified the middle-class, intellectual reaction in his disgust for all bloody sports, publicly outlawing any mention of cockfighting or pugilism in the pages of his best-known periodical, the Examiner. ${ }^{20}$ From the other end of the political scale, boxing and blood sports in general are seen to be so outwith Hannah More's moral compass that she barely makes mention of them, except to condemn. Strictures on the Modern System of Female Education (1799) offers a derisory reference to sport as failing 'to qualify a woman to perform the duties of life' and an attack on horse-racing as an 'unchristian' diversion which is allied to a 'criminal spirit of gambling' ${ }^{21}$

Similarly, Mary Wollstonecraft's Vindication of the Rights of Woman rarely stoops to an explicit tirade against violent sports such as boxing, since this was a world, in the ordinary run of things, closed to women, or to polite women at least. Wollstonecraft does, however, make explicit her disapproval of rough boys' games. Boys, she says, catch an 'habitual cruelty' at school, where they learn to torment animals - a widespread 'sport' that 
Wollstonecraft deplores and claims leads boys later in life to exercise 'domestic tyranny over wives, children, and servants' (Works, v. 244). She also, interestingly, uses this same argument to condemn boxing in her work as a reviewer for Johnson's radical periodical, the Analytical Review, which gave her the remit to include books and novels about sport. Her reaction was typically condemnatory. ${ }^{22}$ In 1790 , she approvingly recycled the anti-boxing arguments of the Reverend Edward Barry in her review of his pamphlet, 'A Letter on the Practice of Boxing. Addressed to the King, Lords, and Commons' (1789):

This author animadverts, with great propriety, on the barbarous customs of boxing in cold blood, as a species of very pernicious gambling; shewing, at the same time, the other bad consequences, which it has a tendency to produce in society. ${ }^{23}$

Although the objection, stemming from religious and moral concerns, that the 'barbarous' custom of 'boxing in cold blood' constitutes little more than 'a species of very pernicious gambling' was hardly new and had been the stock response of Evangelicals for some time, what is noteworthy about Barry's pamphlet, and Wollstonecraft's endorsement of it, is the insistence that boxing is the most un-English of sports.

Wollstonecraft cites verbatim Barry's view that boxing constitutes a perversion of 'civilised' English values:

If, therefore, in these several instances, boxing is so contrary to the maxims of a civilized government, and is neither directed by courage, necessity, nor by advantage to society; it follows, that these bloody scenes must be a brutal sport, unworthy of Englishmen!

These spectacles afford no entertainment to the warrior, or the valiant man - to the man of refinement - to the scholar-or really to the gentleman! No, it gives pleasure principally to those who are charmed with the uproars of a bull-baiting, or the cruelties of a cock-fighting; minds of this cast crowd to the field of carnage, and, like leeches, thrive on the blood that is spilt! $!^{24}$

The association of boxing with the sanguinary cruelties of bull-baiting and cock-fighting consigns the sport to the outer reaches of humanity, making it the preserve of the uncultivated tastes of the ill-educated and here dehumanised mob who 'crowd to the field of carnage'. This and the following image of leeches thriving 'on the blood that is split' uncannily pre-empt the powerful symbolism of Shelley's anti-monarchical sonnet 'England in $1819^{\prime}$ where, in a reversal of Barry's image, it is the King and his ministers, not the mob, who gorge themselves leech-like on England's blood. 'Princes, the dregs of their dull race' (1. 2) cling to England, bloating themselves on the riches of fields they did not help to till and wealth they did not work for until, satiated, 'they drop, blind in blood, without a blow' (1. 6). The future George IV, who appointed boxers to act as ushers at his coronation is, in Shelley's estimation, one such 'Prince'.

The Reverend Barry's effusive denunciation of the uncivilised, ungentlemanly, and quintessentially un-English boxing enthusiast as a national parasite typifies the strength of the resistance to boxing in the 1790s from the middle-class intelligentsia. In the context of such overwhelming opposition, Hazlitt's 'The Fight' stands out as a remarkable vindication of the sport from the pen of a polite, albeit iconoclastic, middle-class radical. His defence of the sport is all the more remarkable for coming at precisely the moment that boxing's reputation was entering a sharp moral decline. In the 1820s, at the height of its popularity (some 25,000 people are said to have attended the Neat-Hickman match described by Hazlitt) boxing became increasingly associated with 
corruption and criminal activity. That Hazlitt was aware of the sport's decline in status is suggested, as David Higgins has noted, by his inclusion of 'Tom Turtle', the trainer with whom he shares a coach on route to the Neat-Hickman contest, who is a 'thinly-disguised version of John Thurtell, a fraudster and gambler who was to be famously tried and executed for murder in $1824^{\prime} .^{25}$

In spite of boxing's increasingly questionable status, Hazlitt strives to reposition the sport from its association with the twin poles of Regency society, the 'highs' and the 'lows', towards the excluded middle class. The scene of 'The Fight' is unmistakably one of middle-class Romantic sociability. In his description of the routes travelled to and from rural Hungerford where the fight took place, the conversations held with boxing cronies along the way, the inns frequented and, not least, the habits and manners of 'The Fancy', the name given to the fraternity of boxers, their followers, and their more socially elevated, sometimes aristocratic, backer-patrons, Hazlitt paints the social spaces of Regency England in a manner designed to appeal to the tastes of the New Monthly Magazine's cultured readers.

Consider, for example, the essayist's description of a man he meets at in the inn at Hungerford 'as a fine fellow, with sense, wit and spirit, a hearty body and a joyous mind, free-spoken, frank convivial - one of that home English breed that went with Harry the Fifth to the siege of Harfleur - "standing like greyhounds on the slips", \& $c^{\prime}(146)$. He tells us that this epitome of English manhood makes 'mince-meat' of a fellow 'drunken, stupid, red-faced, quarrelsome, frowzy farmer' (146). But the battle is verbal rather than physical and a potentially violent outcome is averted by the comedic farmer falling into a drunken stupor before having the chance to face down his 'laughing persecutor' (147). Hazlitt compares the spectacle to a scene worthy of 'Hogarth to paint' (147). He stops short, however, of emulating that artist's satirical preoccupation with the squalid, which would be a thing unsuitable for the eyes and ears of Hazlitt's 'Ladies'.

It is worth emphasising that 'The Fight' opens with an address to the most obviously 'refined' portion of the New Monthly's readership, namely the 'Ladies', to whom his essay is dedicated:

Ladies! it is to you I dedicate this description; nor let it seem out of character for the fair to notice the exploits of the brave. Courage and modesty are the old English virtues; and may they never look cold and askance on one another! Think, ye fairest of the fair, loveliest of the lovely kind, ye practisers of soft enchantment, how many more ye kill with poisoned baits than ever fell in the ring; and listen with subdued air and without shuddering, to a tale tragic only in appearance, and sacred to the FANCY!

A number of modern readings of 'The Fight' have dwelt upon the apparent inappropriateness of this dedication. Hazlitt's infatuation with the serving girl Sarah Walker at the time he witnessed the Neat-Hickman fight is one reason given for what might seem a strange preoccupation with the ladies in this über-masculine context. His suggestion that the arts of feminine seduction are deadlier than the physical blows administered by male boxers has been traced directly to the capricious Sarah's ill treatment of him. ${ }^{26}$ Few commentators, however, have linked the remark into broader discussions of Hazlitt's heavily romanticised depiction of boxing as a sport suitable for middle-class eyes or to the wider issue of women's relationship to sport during the Romantic period.

In what follows, I expand on the connections between Wollstonecraft and Hazlitt, focusing in the first instance on their shared insistence that acting morally involves shunning ostentatious 
behaviour in favour of a more modest style, a mode of self-restraint which extends to their own writing practices. Both Hazlitt and Wollstonecraft demonstrate their awareness that prose style has class resonances and both specifically address their work to genteel readers.

III

It is a nice biographical coincidence that the young William Hazlitt recalled being struck in the summer of 1796 by seeing William Godwin engrossed in conversation with Mary

Wollstonecraft. He remembered 'she seemed to turn off Godwin's objections to something she advanced with quite a playful, easy air' ${ }^{\prime 27}$ That Hazlitt was himself a self-consciously stylish writer, one who staked his claims playfully yet forcefully though networks of allusion and repetition, is a matter of record. ${ }^{28}$ As a late-Romantic periodical essayist, he occupied a 'new literary register', one described by Gregory Dart as 'somewhere between the élite reviews and the sensationalist tone of broadsheets and mass magazines' ${ }^{29}$ 'The Fight' typifies Hazlitt's ability to combine different registers (the literary and the popular, or the high- and the low-brow) 'in a manner at once casual and densely considered ${ }^{\prime} .^{30}$ Take the essay's opening paragraph, which is a mixture of high and low registers. Self-absorbed meditation (of the type usually associated in Romantic literature with the solitary rural pedestrian or the Wordsworthian 'egotistical sublime') is infused with Shakespearean allusion and inserted into the (oddly inappropriate) urban low-life context of the London boxing tavern owned by the former prize-fighter Randall: ${ }^{31}$

Where there's a will, there's a way,-I said so to myself, as I walked down

Chancery-lane about half-past six o'clock on Monday the $10^{\text {th }}$ of December, to inquire at
Jack Randall's where the fight the next day was to be; and I found 'the proverb' nothing 'musty' in the present instance. I was determined to see this fight, come what would, and see it I did, in great style. It was my first fight, yet it more than answered my expectations. (140)

Hazlitt's invitation to the polite readers of the New Monthly to experience vicariously his boxing adventures takes an initially unsettling course as he narrates his journey towards as Jack Randall's less than salubrious public house. Recalling the ill-mannered landlord's drunken and belligerent treatment of him in the past, he avoids entering the establishment, explaining his decision by way of the parenthetical comment '(for Jack is no gentleman)' (140). A likely disagreeable low-life scene is avoided and the emphasis shifts instead to Hazlitt's account of his conversation with Joe Toms, who emerges from the aforesaid public house, apparently unscathed by liquor, to join Hazlitt in a perfectly gentlemanly conversation and convivial walk across town. There is nothing in the opening scene of 'The Fight', notwithstanding the setting of London streets and alehouses, that might be deemed morally offensive to the polite female reader, who is protected from direct exposure to the seedier elements of the boxing world.

As with Hazlitt, Mary Wollstonecraft envisages her primary audience to be the respectable middle classes. Vindication of the Rights of Woman, which is fundamentally a treatise on female education and conduct, is addressed to women 'in the middle class', as the author puts it, 'because they appear to be in the most natural state.' (Works, v. 75). Accordingly Wollstonecraft aims to write in a natural, transparent and unaffected style that mirrors the 'naturalness' linked with the middle classes. She announces at the beginning of her text: 
I shall disdain to cull my phrases or polish my style; - I aim at being useful, and sincerity will render me unaffected; for, wishing rather to persuade by the force of my arguments, than dazzle by the elegance of my language, I shall not waste my time in rounding periods, or in fabricating the turgid bombast of artificial feelings.

(Works, v. 75-6)

The 'turgid bombast of artificial feelings', a phrase almost pugilistic in its demonstrativeness, is associated throughout Rights of Woman with the social corruption of manners evident in the affected displays of femininity and false sensibility of which Wollstonecraft accuses the fashionable upper classes. In reaction to such 'falsity', she urges middle-class women to behave modestly, according to the dictates of inner reason. 'Modesty, temperance, and self-denial', she says, 'are the sober offspring of reason' (Works, v. 152); they are, in other words, qualities innate in the mind rather than the product of social conditioning. At the same time, Wollstonecraft does not diminish the power of culture to shape - or to 'distort' - human nature and it becomes clear in this sense that she sees English culture and the English educational system as somehow more natural than the French. 'In France', she says, 'boys and girls, particularly the latter, are only educated to please, to manage their persons, and regulate their exterior behaviour' (Works, v. 151).

French women represent the worst excesses of the English upper classes. One of Wollstonecraft's most striking metaphors for the vain society lady is her periphrastic image of the 'feathered race'. '[W]hy do they not discover', she protests, when "'in the noon of beauty's power," that they are treated like queens only to be deluded by hollow respect, till they are led to resign, or not assume, their natural prerogatives? Confined then in cages like the feathered race, they have nothing to do but to plume themselves, and stalk with mock majesty from perch to perch' (Works, v. 125). If modesty is crucial to Wollstonecraft's ideal of the rational, middle-class English woman, it is also, I want to suggest, Hazlitt's watchword in 'The Fight' for his idealised version of English middle-class masculinity. Boxing literature of the day, such as Pierce Egan's pugilistic history, Boxiania (4 vols, 1812-29), typically moralised on the spectacle of a fight, passing judgment on the protagonists, reviewing whether fair play had been observed, and commenting on the appearance and behaviour of the crowd. Indeed, boxing itself, despite its overtly violent nature, was actually a highly regulated sport in the Regency period, governed by a set of strictly-monitored fight rules (the 'Broughton Rules' after their eighteenth-century compositor, Jack Broughton), such that moral judgment was seamed into contemporary newspaper accounts of major fights. Hazlitt's 'report' on the Neate-Hickman contest is distinguished from the run of boxing literature, however, by virtue of its investment in a middle-class ideal of masculine virtue. It is an ideal, moreover, which hinges on the importance of behaving modestly.

'Courage and modesty', Hazlitt announces at the opening of his essay, 'are the old English virtues' (140). Even though modesty is coupled with courage as the essence of English manhood, it is arguable nonetheless that it retains its feminine connotations and at the very least might be seen to belong more properly within an eighteenth-century discourse of sensibility than a Regency boxing report. In terms recalling Wollstonecraft's insistence in Rights of Woman on the necessity for women to avoid forms of ostentatious self-display and act modestly, according to their inner reason, Hazlitt enjoins prize-fighters to shun flamboyant display; in other words, to behave modestly. In this respect, he joins Wollstonecraft in her attempt to wrest the meaning of modesty from its contemporary 
gendered meaning of female chastity and to move in the more radical direction of seeing it as a universal cross-gendered attribute of mind. ${ }^{32}$

An essential element of the build up to major fights was a theatrical display by the combatants of their physical prowess. It was usual for prize-fighters to enter the ring, gladiatorial style, in such a way as to heighten the drama of the forthcoming event and increase the audience's sense of anticipation. In this context it is remarkable that Hazlitt, describing Tom Hickman's pre-match posturing, attacks him precisely on the grounds of his immodest demeanour. It is true that in doing so he is partly following a frequent criticism made of Hickman's lack of moral rectitude. Rumours of his cruelty as well as his boastfulness were widespread (one report had it that he drunkenly broke a dog's back with a poker) $;^{33}$ it is all the more notable, then, that Hazlitt, who evidently leaves out of his essay such unsavoury details, describes him as unmanly. ${ }^{34}$ Hickman's swaggering boast to the crowd of his anticipated victory over his opponent Neate, a butcher by trade ('I'll knock more blood out of that great carcase of thine, this day fortnight, than you ever knock'd out of a bullock's!') (148-9) earns Hazlitt's contempt: 'It was not manly, 'twas not fighter-like. If he was sure of the victory (as he was not), the less said about it the better. Modesty should accompany the Fancy as its shadow' (148-9). Boxing is figured here as a form of ethical discourse, and the bully Hickman has not learned the moral lessons which it affords. Like Wollstonecraft, Hazlitt views sports as pedagogically resonant, but where the Rights of Woman sees them as destructive, Hazlitt distinguishes the ring as a rough-hewn school of manners.

For Hazlitt, Hickman, also known as the 'Gas' or 'The Gas-man' (supposedly due to his occupation as a lamp-lighter), is guilty of excessive arrogance:
[T] he Gas-man came forward with a conscious air of anticipated triumph, too much like the cock-of-the-walk. He strutted about more than became a hero, sucked oranges with a supercilious air, and threw away the skin with a toss of his head. (150)

Notwithstanding obvious differences of social class and sex, Hazlitt's description of the uncultivated Hickman strutting his stuff echoes Wollstonecraft's negative image in Rights of Woman of the feathered society lady, and the import of both observations is alike: namely, the construction of a middle-class ideal of modest conduct. Just as Wollstonecraft sees the adulation of society women as dangerously misguided and inevitably short-lived - " "in the noon of beauty's power"' , women 'are treated like queens only to be deluded by hollow respect' - so Hazlitt moralises against Hickman's presumption that his reign will continue unbroken. In the wake of his defeat by Neate Hazlitt writes that 'the Gas' 'had presumed too much on himself, which had made others presume on him' (148). 'This spirited and formidable young fellow', says Hazlitt, 'seems to have taken for his motto the old maxim, that "there are three things necessary to success to life-Impudence! Impudence! Impudence!" It is so in matters of opinion, but not in the Fancy' (148).

In admonishing Hickman for his hubris, the essayist naturalises a middle-class, bourgeois emphasis on modesty as an essential attribute of the English masculinity symbolised by the 'Fancy'. His protracted criticism of Hickman's want of modesty is also, it becomes clear, a moral statement on the characters of pugilists in general, who are judged as representatives of English masculinity according to whether they behave modestly, like the aptly-named Neate, who, Hazlitt tells us, addresses the crowd 'with a modest cheerful air' (150), or, like the equally well-named 'Gas', who is boastful and 
self-regarding. 'The best men', proclaims Hazlitt, 'were always the best behaved':

A boxer was bound to beat his man, but not to thrust his fist, either actually or by implication, in every one's face. Even a highwayman, in the way of trade, may blow out your brains, but if he uses foul language at the same time, I should say he was no gentleman. A boxer, I would infer, need not be a blackguard or a coxcomb, more than another. (149)

The idea that a highwayman no less than a boxer should behave like a gentleman all but fuses differences of class and trade in the name of a universal system of middle-class manners. And it is the figure of the low-bred boxer, here as elsewhere in 'The Fight', who symbolises the natural authority of the middle-class values advocated by Hazlitt. A sportsman should be 'a fine, sensible, manly player ${ }^{\prime 35}$ such as his friend the fives nonpareil John Cavanagh whose obituary Hazlitt composed for the Examiner in 1819.

Hazlitt's first-person narrative makes moral propositions, phrased as personal opinions, which are there to be accepted or resisted. The authority of his representation of middle-class manners, resides, however, in the effacement of its own status as a class-prejudiced discourse. What is unspoken and therefore not open to negotiation is the 'naturalness' of a bourgeois construction of masculinity that unifies class difference and underwrites simultaneously a unifying myth of English superiority. The unifying potential of that myth is further invoked in the many scenes in this essay that I would describe as the manifestation of 'Romantic Sociability', the title of Gillian Russell and Clara Tuite's influential collection of essays on social networks and literary culture in Britain between the years 1770 and $1840 .{ }^{36}$ The editors define the 'value' of sociality 'in the modeling of culture as a conversation, and the cultivation of the sociable virtues of laughter, clubbability, conviviality, taste and politeness' ${ }^{\prime}{ }^{37}$

One benefit of recent scholarship on Romantic sociability is the way in which it has brought into the foreground the significance of social networks during the Romantic age as against the caricature of the solipsistic, isolated thinker, writer or poet. Certainly Hazlitt's 'The Fight ${ }^{\prime}$ puts a different spin on the figure of the Romantic thinker and walker, two activities that are frequently combined in accounts of Romantic creativity. The self-absorbed solitary wanderer familiar from Romantic-period literature is displaced in Hazlitt's essay by a figure who traverses the social networks of sporting, urban culture on foot-a solitary peripatetic observer at times, but also one who gains inspiration and pleasure in conversation with fellow walkers from the boxing community.

Hazlitt's description of the actual fight between Neate and the Gas occupies less than one third of his essay, the larger portion focusing on the narrator's retrospective portrayal of the conversations held with his companions on the way to the fight and his reflections upon the scenes witnessed en route. In a miniature version of the English picaresque, Hazlitt describes his saunter through the streets of London, where he chances upon his boxing pal Joe Toms, and thence his journey of some sixty miles out of the city to Hungerford's rural hinterland, where he is joined on the return leg by Jack Pigott, 'a sentimentalist' (153), says Hazlitt, who carries with him a pocket volume of Rousseau's New Eloise. There is throughout an air of conviviality and comradeship, and a feeling of liberty induced by the adventure of going to see a fight. In Hazlitt's words:

Toms and I, though we seldom meet, were an alter idem on this memorable occasion, and had not an idea that we did not candidly impart; and 'so carelessly did we fleet the 
time', that I wish no better, when there is another fight, than to have him for a companion on my journey down, and to return with my friend Jack Pigott, talking of what was to happen or of what did happen, with a noble subject always at hand, and liberty to digress to others whenever they offered. Indeed, on my repeating the lines from Spenser in an involuntary fit of enthusiasm,

'What more felicity can fall to creature,

Than to enjoy delight with liberty'

my last-named ingenious friend stopped me by saying that this, translated into the vulgate, meant 'Going to see a fight'.

In his essay 'On Going on a Journey', published in 1821, the same year as the Neate/Hickman fight, Hazlitt tells us that 'The soul of a journey is liberty, perfect liberty' ${ }^{38}$ The reference here is to solitary, rural pedestrianism. 'I cannot see the wit of walking and talking at the same time', says Hazlitt. 'We go on a journey chiefly to be free of all impediments and of all inconveniences; to leave ourselves behind, much more to get rid of others' ${ }^{39}$ Hazlitt's suspicion that one's personal liberty is infringed upon when walking in company is given an interestingly different treatment in 'The Fight'. Here liberty is associated not with solitude but with the companionship and sociability that define 'Going to see a fight'.

The liberty connoted by the sociable act of going to a fight - and the perambulatory conversations entertained along the way-surfaces elsewhere in Romantic-period writing on walking as the trigger for sexually-free conversation, for a form of libertinism in other words. Robin Jarvis draws attention, for example, to Keats's enjoyment of his companion Charles Armitage Brown's 'bawdy wordplay on the King Arthur Legend' during their walking tour of the Lake District and the Scottish Highlands in the summer of $1818 .^{40}$ In a letter to his brother Tom, in mid-July, Keats wrote:

Here's Brown going on so that I cannot bring to Mind how the last two days have vanished - for example he says 'The Lady of the Lake went to Rock herself to sleep on Arthur's seat and the Lord of the Isles coming to Press a Piece and seeing her Assleap remembered their last meeting at Cony stone Water so touching her with one hand on the Vallis Lucis while [t] he other un-Derwent her Whitehaven, Ireby stifled here clack man on, that he might her Anglesea and give her a Buchanan and said. ${ }^{41}$

Comic embellishment tinged with lewdness also enters into the poet's account of his ascent of Ben Nevis. Keats inserts into his narrative 'a bawdy piece of verse drama about a querulous Mrs. Cameron who nearly falls prey to the sexual appetite of the mountain: "I shall kiss and snub / And press my dainty morsel to my breast'." ${ }^{42}$ Such bawdy intrusions into the aesthetic narrative code of travel writing are described by Jarvis as 'a vein of "Cockney carnivalesque" ', which, he argues, holds a potentially radical political charge. ${ }^{43}$ Influenced by Mikhail Bakhtin's work on the semiotics of parody, Jarvis contends that Keats's permissive humour had the effect of liberating the consciousness from the prison-house of a particular hegemonic discourse, and therefore prepared the ground for the kind of relativized understanding of reality in which change might be possible'. ${ }^{44}$

Elements of the Keatsian 'Cockney carnivalesque' (though interestingly not the bawdy) might be said to reappear in the walking-narrative of 'The Fight' in Hazlitt's occasional adoption of a 'flash' style, which, in the manner of the 'bawdy' language used by Keats, could be seen to possess an incipient 
counter-cultural charge that links boxing to the radical political fringe of Romanticism. Hazlitt studs his essay with italicised flash words and phrases, such as 'blue ruin' (cheap gin), 'scratch' (a line drawn across the ring where the boxers position themselves at the beginning of a round), or 'pluck' (manly spirit), primarily in order to position himself as one of the 'Fancy'.

Defined by Gregory Dart as a combination of 'cant', a street language 'formed for the purposes of secrecy' associated with the criminal underclasses, and 'slang', the language of a coterie, 'indulged in to appear familiar with life, gaiety, town humour', 'flash' introduces an element of the exotic and the illicit into Hazlitt's erstwhile middle-class mode of address. ${ }^{45}$ As with the fleeting reference to Jack Randall's drinking establishment, however, the polite reader is offered an illicit, perhaps tantalising, glimpse of the carnivalesque criminal underworld of boxing but the sight is viewed vicariously, at a safe distance. In other words, the armchair spectator of the Neate-Hickman contest is invited to undertake a form of class tourism that exposes him or her to the under-class elements of the boxing world but not at the loss of moral decency and decorum.

In comparison with Keats's bawdy pedestrian narrative, Hazlitt's essay is noticeably chaste, remarkably so given its male environment of boxing taverns, fight-rings and the fancy. Hazlitt reports that he and his sentimental boxing friend Pigott speak only of 'noble' subjects. Kasia Boddy insightfully traces a connection in 'The Fight' between 'boxing, sentiment and (political as well as psychological liberty) $)^{\prime} ;{ }^{46}$ it is fair to say, however, that the essay does not amount to an exercise in politically radical writing. Instead, Hazlitt's great achievement in 'The Fight' is the realignment of popular sports in Romantic and literary culture with the discourse of social morality and sociability. This is, at root, an essay in middle-class male conduct.
Russell and Tuite's definition of Romantic sociability as the construction of culture as 'a conversation' allows us to see Hazlitt modeling boxing culture in terms that echo their emphasis on the cultivation of 'the sociable virtues of laughter, clubbability, conviviality, taste and politeness'. In a deliberate act of poeticizing, Hazlitt transforms the boxing arena into a theatre of middle-class modern heroism and male virtue. The fight scenes, although they contain many of the markers of realist description (dates, place names, times, and so on) are heavily romanticised. For instance, Hazlitt writes admiringly of the closing stages of the fight: 'to see two men smashed the ground, smeared with gore, stunned, senseless, the breath beaten out of their bodies; and then, before you recover from the shock, to see them rise up with new strength and courage, stand ready to inflict or receive mortal offence, and rush upon each other "like two clouds over the Caspian" - this is the most astonishing thing of all' (152). Yet, as contemporary reports by the boxing journalist Pierce Egan had it, Hickman, who was the eventual loser in the contest, behaved with considerably less than classical heroism. As Egan describes it, in a plainer idiom than his customary mock-heroics, 'instead of putting his arms to fight, he endeavoured to button the flap of his drawers in a confused state' and when he went up to the scratch again was immediately knocked out. ${ }^{47}$ Yet in Hazlitt's account, 'this is the high and heroic state of man' (152). This kind of romanticising is fundamental to Hazlitt's projection of boxing to the middle classes as a moral and noble sport, an instrument, ultimately, of national self-definition.

The legitimacy of boxing resides for Hazlitt in the kind of national moral conduct that he identifies in the 'best men', prize-fighters such as Neate, whose heroics inside the ring bear classical comparison - Neate is described as a 'modern Ajax' to Hickman's 'Diomed' (150). Classical analogy notwithstanding, Hazlitt 
makes it clear that boxing in the Regency age is a sport that resonates with modern urban cultural values. Far from being like horseracing and shooting the sport of country Tory squires, such as the boorish Squire Tyrell of William Godwin's Caleb Williams (1794), boxing has an appeal to modern middle-class men as part of the wider sphere of masculine sociability.

IV

There is in Jacobin fiction of the 1790s a common suspicion of sports of the hunting field and the boxing ring. The Jacobin argument against sports, specifically male blood sports, such as hunting and boxing, is that they foster cruelty in the individual leading ultimately to anti-social behaviour. It is no accident that aforesaid boxing and hunting Squire Tyrell-a man of 'muscular and sturdy' ${ }^{\prime 4}$ stature, as Godwin describes him - is also a bully whose natural aggression, far from being disciplined by sporting activity develops out of control, resulting in the early demise of his once-loved cousin Miss Emily, who falls foul of his cruel and competitive jealousy. Where Hazlitt sees muscled prize-fighters as modern Greek heroes, Godwin sees merely brute physical force and while in Hazlitt's account boxing teaches gentlemanly conduct, in Godwin's sport is a malign influence that corrupts early on a boy's character and teaches only selfishness and cruelty.

Whether from the pens of boxing enthusiasts such as Hazlitt or detractors such as Godwin, and indeed Wollstonecraft, the language used to describe or denounce sport during the Romantic period often possesses a pedagogic dimension. Thus when

Wollstonecraft turns her attention in Rights of Woman to the type of physical activities that girls might engage in she focuses the discussion with prescient exactness on the school curriculum. '[B]oys and girls, the rich and poor', she argues, should be educated together in national elementary day schools and 'to prevent any distinctions of vanity, they should be dressed alike, and all obliged to submit to the same discipline, or leave the school' (Works, v. 240). Stressing the importance of outdoor physical exercise alongside academic pursuits both for young boys and girls she writes that:

The school-room ought to be surrounded by a large piece of ground, in which the children might be usefully exercised, for at this age they should not be confined to any sedentary employment for more than an hour at a time... Reading, writing, arithmetic, natural history, and some simple experiments in natural philosophy, might fill up the day; but these pursuits should never encroach on gymnastic plays in the open air.

(Works, v. 240)

Wollstonecraft's far-sighted vision of a free, national co-educational school system where children are taught to discipline their bodies, to acquire 'strength of body and mind' (Works, v. 242), as she puts it, is part of her wider humanitarian mission to teach children to be respectful not just of themselves and each other but also to learn 'the exercise of compassion to every living creature'. 'Humanity to animals', she argues, 'should be particularly inculcated as a part of national education' (Works, v. 243). Echoing Rousseau's ideal of a 'natural' education untainted by the corruptions of modern society, Wollstonecraft suggests that those 'amongst the lower class' show more '[t]enderness for their humble dumb domestics' than the upper classes because they are closer to the 'savage' state (Works, v. 243-4).

'Civilization', she explains:

prevents that intercourse which creates affection in the rude hut, or mud hovel, and leads uncultivated minds who are only depraved by the refinements which prevail in the society, where they are trodden under foot by the rich, to domineer over them to 
revenge the insults that they are obliged to bear from their superiours.

(Works, v. 244)

A narrative of gender reform circumscribes the emphasis on the need to treat animals well. As Wollstonecraft sees it, modern society has corrupted both men and women to the point that, in her words: 'The lady who sheds tears for the bird starved in a snare, and execrates the devils in the shape of men, who goad to madness the poor ox, or the whip the patient ass, tottering under a burden above its strength, will, nevertheless, keep her coachman and horses whole hours waiting for her when the sharp frost bites' (Works, v. 244). Even more reprehensible is the mother who lavishes attention on her lap dog while neglecting her children: 'she who takes her dogs to bed, and nurses them with a parade of sensibility, when sick, will suffer her babes to grow up crooked in a nursery' (Works, v. 244). In similar fashion, the man who can happily can happily chase a fox to its death, cheer on a fighting cockerel or watch another man beat his opponent, bloodied and smeared to the ground, is likely in Wollstonecraft's estimation to follow the path of libertinism and domestic tyranny.

The 'false' sensibility paraded by the lap-dog owner is analogous in Wollstonecraft's philosophy to the spectacle of brute masculine force exhibited in the boxing ring. Just as sport is socially corruptive of male virtue, so excessive sensibility is a perversion of a woman's duty to 'exercise compassion'. 'Exercise' on the other hand is distinguished from modern boys' cruel sports as a crucial to ensuring the development of a healthy body, which is the counterpart of a healthy mind. The message of Rights of Woman that boys' sports provide poor moral lessons which damage the adult male exists alongside the apparently contradictory position that physical exercise, coupled with the 'judgement' that is 'acquired by reflection' is the root the of moral improvement of both the sexes. 'Exercise and cleanliness', Wollstonecraft affirms, 'appear to be not only the surest means of preserving health, but of promoting beauty... To render the person perfect, physical and moral beauty ought to be attained at the same time' (Works, v. 243).

At this point the question begs asking of what it is that differentiates the malign influence of physical sports for Wollstonecraft from the moral benefits of physical outdoor exercise. The answer has to do with two things: first, the association of male sports with the pernicious, competitive vice of gambling and, second, an incipient mistrust of all-male social crowds. The type of collective male sociability rendered in a positive light in Hazlitt's 'The Fight' can only arouse distrust in Wollstonecraft. Sometimes this is manifested in a form of sexual suspicion of homosexual behaviour. Wollstonecraft's fear of the male crowd is emblematised in the disturbing bestial image from the penultimate chapter of Rights of Woman, 'On National Education', of the 'nasty indecent tricks' boys learn at boarding school, 'when a number of them pig together in the same bedchamber' (Works, v. 236). Scenes of collective masculinity in Rights of Woman are almost always freighted with an ideological critique of male violence and sexuality.

Wollstonecraft is unable to represent a male crowd in anything other than negative terms of sexual violence, competitiveness, and power over women. A man who gambles is not, in Wollstonecraft's view, a rational creature; rather, he is a slave to selfish impulse and-if left unchecked - a potential bully and tyrant who privileges his own desires above family duties and responsibilities. Similarly, the flirtatious, fashionable woman reared on a diet of vanity, self-love and the feminine accomplishments designed to make a good impression in society is not well equipped for the duties of the rational wife and mother. The idea, in her time, that the stereotypically 
fashionable lady could also be a rational woman (that she could lavish her attention on needlework or music or dressing well and simultaneously prove a good mother) is as antithetical to Wollstonecraft as the possibility that the boxing, cudgel-playing, hunting and shooting Squire Tyrell of Godwin's fiction could prove a rational, compassionate man. In Caleb Williams, Godwin describes the damaging consequences of Tyrell's early rejection of book-learning in favour of lessons from his social inferiors, the 'groom and the game-keeper':

Under their instruction he proved as ready a scholar, as he had been indocile and restive to the pedant who held the office of his tutor. It was now evident that his small proficiency in literature was by no means to be ascribed to want of capacity. He discovered no contemptible sagacity and quick-wittedness in the science of horse-flesh, and was eminently expert in the arts of shooting, fishing, and hunting. Nor did he confine himself to these, but added the theory and practice of boxing, cudgel play, and quarter-staff. These exercises added tenfold robustness and vigour to his former qualifications.

His stature, when grown, was somewhat more than six feet, and his form might have been selected by a painter as model for that hero of antiquity, whose prowess consisted of felling an ox with his fist, and then devouring him at a meal. ${ }^{49}$

If, as we have seen, Hazlitt elevates contemporary prize-fighters by comparing them with the heroes of Greek antiquity, Godwin by contrast, and also Wollstonecraft, is suspicious of mere physical prowess, which suggests a dominance of bodily over moral strength. Hazlitt, on the other hand, constructs the boxing world as one of convivial male sociality, infused by sentiment, humour, and, above all, good manners. In his account, individual men grouped together learn to act morally.

With historical hindsight, Wollstonecraft's humanitarian and gender-driven contempt for boxing can be seen to have triumphed over Hazlitt's attempt to reconfigure the image of the British boxer and of the sport in general along moral and middle-class lines. His was a remarkable, if ultimately failed, attempt to transfuse a Wollstonecraftian emphasis on the virtues of modesty and rational self-restraint into a symbolically and ethically-charged account of a British prize-ring, with the sporting essay recast as conduct book.

By the age of Queen Victoria few respectable middle-class people would associate themselves with boxing and the idea that the monarch or her consort Prince Albert would patronise the ring as George IV and his brother had before them was unimaginable. ${ }^{50}$ As the sporting historian John Lowerson has demonstrated, the withdrawal of the middle class from active participation in boxing was complete well before the end of the nineteenth century. ${ }^{51}$ Boxing remained confined to amateur pugilism in public schools and universities at the top end of the social scale (in part because of the drive for a 'muscular Christianity'), where it was thought to help 'counteract what many saw as the soft-hearted ultra-civilisation of too many Edwardian sensibilities', and to working-class clubs at the bottom, fighting-for-cash, run, says Lowerson, 'by small-scale entrepreneurs who were closer to their audiences rather than in any model of middle-class athletic assumption of ethical virtue'.52

I want to conclude by returning to my opening claim about Hazlitt's construction of the Regency boxing world as a culture of Romantic sociability. In his use of the written word Hazlitt achieved a goal that permanently eluded Wollstonecraft, namely an ability to embody the social virtues of inclusivity and communality in writing. The Hazlittian ' $\mathrm{I}$ ' of 
the 'The Fight' emerges as a distinct voice ironically only in order to emphasise the collectivity of the boxing fraternity, which, we recall, even includes the 'Ladies', to whom the description is dedicated. Boxing's politically radical credentials are highlighted during the Regency in, for example, the sport's association with the radical-freedom-fighter-poet of the age, Lord Byron and with his friend the Whig satirist Thomas Moore. Which is to not say that boxing was itself a politically radically pastime; however, in the context of boxing's radical associations it is possible to see Hazlitt's emphasis on the sociability of the boxing community as continuing to suggest a connection between boxing and social freedom, albeit that this is a form of liberty circumscribed in Hazlitt's account by the internalised rules of good moral conduct. In contrast, the Wollstonecraftian voice can seem fractured and solipsistic. Indeed, by her own admission, it has to be so since hers is above all an anticipatory vision: 'Rousseau', she says, 'exerts himself to prove that all was right originally: a crowd of authors that all is now right: and I, that all will be right' (Works, v. 84). The collective rather than the individual voice of Rights of Woman (the putative voice, perhaps, of the sports team-player or the communal spectator) is a ghostly presence, hovering on the margins of the possible, the state of things yet to be realised.

\section{Department of English Cardiff University}

\section{Notes}

1. Mary Wollstonecraft, Vindication of the Rights of Woman, 1792, in Janet Todd and Marilyn Butler, eds., The Works of Mary Wollstonecraft (7 vols, London, 1989), v. 114. Hereafter abbreviated in the body of the essay as Works and identified by volume number.

2. William Hazlitt, 'The Fight', in William Hazlitt, The Fight and Other Writings, ed. Tom Paulin and David Chandler (London, 2000), 140-56; 149.
Hereafter identified in parentheses in the body of the essay by page number.

3. The phrase is Duncan Wu's, William Hazlitt: The First Modern Man (Oxford, 2008), 51.

4. Jeffrey N. Cox, 'Keats in the Cockney School', Romanticism, 2.1 (1996), 27-39; 33.

5. Ibid., 36.

6. Nicholas Roe graphically describes scenes that the young Keats would have witnessed during his work at Guy's in his biography of the poet, John Keats: A New Life (New Haven and London, 2012). He notes that: 'As dresser, Keats would have had to participate in operations, witnessing harrowing scenes at the operating table and being required to put right any damage inflicted', 91 .

7. Ibid., 285.

8. The Journal of Thomas Moore, ed. Wilfred S. Dowden (7 vols, Newark, 1983), i. 96-7.

9. See Jonathan Bate, John Clare. A Biography (London, 2005), 437. Bate notes that in the spring of 1840 the poet was preoccupied by thoughts of sex and boxing, two obsessions which he united in a 'cryptic fragment linking the name of Byron to Springfield, the house where Dr Allen's [the keeper of the asylum] female patients lived:

$$
\begin{aligned}
& \text { Boxer Byron } \\
& \text { Made of Iron, alias } \\
& \quad \text { Box-iron } \\
& \text { At Spring-field' }
\end{aligned}
$$

10. Ibid., 415 .

11. Cited in ibid., 438 .

12. Ibid.

13. Francesca Cuojati, 'John Clare: The Poetics and Politics of Taxonomy', in The Exhibit in the Text: The Museological Practices of Literature, ed. Caroline Patey and Laura Scuriatti (Bern, 2009), 29-48, 45. Cuojati interestingly weaves the example of 'flash' language into her broader argument that Clare eschewed all attempts at containment and classification, a resistance to authoritative legislature that led him to identify with gypsies and boxers alike.

14. See, for example, 'The Gypsy's Camp', The Village Minstrel, and Other Poems (2 vols, London, 1821).

15. Modern critical interest in Romantic-era boxing and its relation to literary writing of the period includes Kasia Boddy's exhaustive study, Boxing: A Cultural History (London, 2008), Cuojati's essay, op. cit., Gary Dyer, 'Thieves, Boxers, Sodomites, Poets: Being Flash to Byron's Don 
Juan', PMLA, 16.3 (May 2001), 562-78; David Higgins, 'Englishness, Effeminacy, and the New Monthly Magazine: Hazlitt's "The Fight" in Context', Romanticism, 10.2 (2004), 173-90; David Snowdon, 'Hazlitt's Prizefight Revisited: Pierce Egan and Jon Bee's Boxiana-Style Perspective', Romantic Textualities: Literature and Print Culture, 1780-1840, 20 (Winter 2011). Online: Internet (date accessed: 30/08/2012). www.romtext.org.uk/issues/rt20.pdf, 24-44; and John Strachan, 'Romanticism, Sport, and Late Georgian Poetry', in A Companion to Romantic Poetry, ed. Charles Mahoney (Oxford, 2001), 374-92.

16. Thomas Moore, Tom Crib's Memorial to Congress: With a Preface, Notes, and Appendix. By one of the Fancy (London, 1819), reprinted in The Satires of Thomas Moore, ed. Jane Moore, in British Satire 1785-1840, general ed. John Strachan (5 vols, London, 2003), v. 183-227.

17. See note 15 above.

18. See J. C. Reid, Bucks and Bruisers: Pierce Egan and Regency England (London, 1971): 'The Prince of Wales, who became Prince Regent and later King George IV, his brothers, the Duke of York and the Duke of Clarence, later King William IV, were supporters, patrons, bettors; the presence of one or other of these at an "illegal" contest at Moulsey Hurst or Crawley Downs [boxing venues] was sufficient to deter even the most zealous of magistrates from issuing a warrant. Not only did the Prince of Wales attend fights, at least until 1788 , and visit the training-rooms in London, but he cultivated the society of boxers and received them at Court. On 24 July 1821, when he was crowned King, eighteen of the leading pugilists of England, including Cribb, Spring, Belcher, Richmond, Owen, Hudson and Oliver, under the direction of "Gentleman" John Jackson, were chosen by the King to act as Ushers at Westminster Hall, which action at the same time flattered his friends of the Fancy and ensured the absence of outbreaks of rowdyism. Without such patronage and wealthy backers, it is doubtful if pugilism could have survived the constant charges from the respectable as to its brutality and the vigilant persecution from officers of the law; the presence, too, of the nobility and the aristocracy at a bout acted as something of a check on the large, heterogeneous and often pugnacious crowds' (14). 19. Ibid.
20. As noted by John Strachan, 'Fighting Sports and Late Georgian Periodical Culture', in The British Periodical Text, 1797-1835, ed. Simon Hull (Penrith, 2008), 143-69, 155.

21. Hannah More, Strictures on the Modern System of Female Education (1799), in The Works of Hannah More (11 vols, London, 1830), v. 353.

22. See, for example, her review of the epistolary novel Doncaster Races; or, the History of Miss Maitland: a Tale of Truth (1789), which is criticised for lacking authenticity and reproducing in the typical inferior novel's manner 'improbable adventures and unnatural characters' (Works, vii. 135).

23. Mary Wollstonecraft, review of 'A Letter on the Practice of Boxing. Addressed to the King, Lords and Commons. By the Rev. Edward Burry. A.M. M.D. Chaplain to the Lord Bishop of Kildare, 1789', Analytical Review, vol. vi, 1790, in Works, vii. 227.

24. Ibid.

25. David Higgins, 'Englishness, Effeminacy, and the New Monthly Magazine: Hazlitt's "The Fight" in Context', Romanticism, 10.2 (2004), 173-90, 179.

26. Higgins, for instance, writes that 'Hazlitt's self-presentation in "The Fight" was a response to his obsession with Sarah Walker', ibid., 186.

27. Cited in $\mathrm{Wu}$, William Hazlitt, 62.

28. Tom Paulin maintains that Hazlitt's 'essential theme, throughout his career, is the nature of prose style', 'Introduction' to William Hazlitt, The Fight and Other Writings, xiv.

29. Gregory Dart, 'Romantic Cockneyism: Hazlitt and the Periodical Press', Romanticism, 6.2 (2000), 143-62, 148.

30. I have borrowed the phrase from Kasia Boddy's Boxing: A Cultural History (London, 2008), 63.

31. Jack Randall (born in London, into poverty, in 1794) was a famous Regency prize-fighter. On his retirement in 1819, he became landlord of the Hole in the Wall Tavern, in Chancery Lane. While the address is reasonably up-market, the establishment itself was far from high class - witness Hazlitt's reference to Randall's drunken brawling.

32. Vivien Jones argues that modesty in Wollstonecraft's account is 'indistinguishable from the classic conduct-book opposition between acceptable and unacceptable modes of middle-class femininity: inner virtue and "use" compared with 
superficial display'; see 'Mary Wollstonecraft and the Literature of Advice and Instruction', in The Cambridge Companion to Mary Wollstonecraft, ed. Claudia L. Johnson (Cambridge, 2002), 119-40; 127. Even so, as Jones also writes, 'the Dissenting tradition' to which Wollstonecraft belonged 'pulls in a more disruptive direction' (ibid.). For example, an apparently conventional work of conduct such as James Burgh's Thoughts on Education (1747), 'whose widow Hannah', writes Jones, was particularly supportive of Wollstonecraft's project, stresses 'independence of mind over "the superficial opinion of the multitude"' (ibid., 125, 127).

33. David Snowdon reports the story of Hickman's brutality in 'Hazlitt's Prizefight Revisited: Pierce Egan and Jon Bee's Boxiana-Style Perspective', Romantic Textualities: Literature and Print Culture, 1780-1840, 20 (Winter 2011). Online: Internet (date accessed: 30/08/2012). www.romtext.org.uk/issues/rt20.pdf, 24-44, 31.

34. Hickman was a renowned braggart. David Snowdon has written at length on Egan's treatment of him in 'Hazlitt's Prizefight Revisited'.

35. The Complete Works of William Hazlitt, ed. P. P. Howe (21 vols, London, 1930-4), viii. 87.

36. See Romantic Sociability: Social Networks and Literary Culture in Britain, 1770-1840, ed. Gillian Russell and Clara Tuite (Cambridge, 2002).
37. Ibid., 5 .

38. William Hazlitt, 'On Going on a Journey', from Table Talk (1821), in William Hazlitt, Selected Writings, ed. Ronald Blythe (Harmondsworth, 1970), 136.

39. Ibid.

40. Robin Jarvis, Romantic Writing and Pedestrian Travel (Houndmills, Basingstoke, 1997), 197.

41. Letters of John Keats, ed. Robert Gittings (London, 1970), 129; cited in Jarvis, ibid.

42. Jarvis, ibid., 202. Jarvis notes that Robert Gittings omitted the composition from his Letters of John Keats on the grounds of taste, ibid., 232, 17n.

43. Jarvis, ibid., 203.

44. Ibid., 202-3.

45. Gregory Dart, "Flash Style": Pierce Egan and Literary London 1820-28', History Workshop Journal, 51 (2001), 181-205, 191.

46. Boddy, Boxing: A Cultural History, 65.

47. The Egan quotation is cited by Higgins, 'Englishness, Effeminacy, and the New Monthly Magazine', 184.

48. William Godwin, Caleb Williams, ed. Maurice Hindle (Harmondsworth, 1988), 19.

49. Ibid.

50. Boddy's Boxing: A Cultural History underlines the point (76).

51. See John Lowerson, Sport and the English Middle Classes, 1870-1914 (Manchester, 1993).

52. Ibid., 170. 